Proc. Estonian Acad. Sci. Geol., 2001, 50, 1, 24-42

\title{
LITHOSTRATIGRAPHY AND DISTRIBUTION OF TILLS IN THE SAADJÄRVE DRUMLIN FIELD, EAST-CENTRAL ESTONIA
}

\author{
Maris RATTAS and Volli KALM \\ Institute of Geology, University of Tartu, Vanemuise 46, 51014 Tartu, Estonia; mrattas@ut.ee, \\ vkalm@math.ut.ee \\ Received 7 August 2000, in revised form 20 September 2000

\begin{abstract}
Middle and Upper Pleistocene till beds with stratified glaciofluvial and glaciolacustrine deposits constitute the structure of the drumlins in the Saadjärve Drumlin Field. The only interglacial deposits of the area belong to the Karuküla Formation (Holsteinian) at the distal end of the drumlin field. The differences in grain-size distribution, mineralogical and chemical composition are regarded as confirmation of the crucial role of compositional characteristics in determining the stratigraphy of these tills. Analysis shows that the Upper Sangaste (Elsterian) till, the oldest in the area, as well as the Valgjärve (Lower Weichselian) and Võrtsjärve (Upper Weichselian) tills have distinct compositional characteristics. The Lower and Upper Ugandi (Saale glaciation) tills have no lithological differences; thus there may be only one Saalian till in the area. The stratigraphy and distribution of tills in the Saadjärve Drumlin Field proves an accretionary origin of these drumlins. They started to form during Saale glaciation and the formation process lasted for several glacial advances.
\end{abstract}

Key words: till, lithology, stratigraphy, drumlin, Saadjärve Drumlin Field, Estonia.

\section{INTRODUCTION}

The internal structure and formation of drumlins are widely disputed subjects (Menzies 1984; Menzies \& Rose 1987, 1989; Aario \& Heikkinen 1992; Dardis \& McCabe 1994). In some studies a comprehensive, systematic description of the regional variations in till lithology and stratigraphy within an entire drumlin field is given (Menzies 1979; Goldstein 1989). The regional and local variations in till lithostratigraphy reflect the formation of drumlin fields during one or more glacial advances and/or an accretionary origin of drumlins (Goldstein 1989). 
Estonian drumlins are products of one or more glacial advances and are far from being the same age (Rõuk \& Raukas 1989). The main period of formation was likely the general retreat of the last glacier (13000-11000 yr BP), interrupted by temporary short-term advances. The fields of smaller drumlins (Türi, Põltsamaa, Sakala, and Raasiku) consist entirely of a uniform till and were probably formed during one glacial advance (Barkla 1935; Rõuk 1972; Rõuk \& Raukas 1989), although meltwater sand and gravel deposits and several till units are found within many drumlins. So-called stratified drumlins (Hausen 1913) might have formed during multiple ice advances and even during different glaciations. Stratified drumlins are very common in the Saadjärve Drumlin Field (Fig. 1). The internal structure of Saadjärve drumlins has been described in several publications (Hausen 1913; Orviku 1958, 1961; Eltermann \& Raukas 1963; Kajak 1965; Rõuk 1974a, 1974b, 1976, 1984, 1987; Raukas 1978; Rõuk \& Raukas 1989; Raukas \& Tavast 1994). Kajak (1965) first determined five till units in the Saadjärve Drumlin Field from a borehole at Lake Saadjärv (Fig. 1, borehole 251), which, according to current Estonian stratigraphic nomenclature (Raukas \& Kajak 1995), represent the Võrtsjärve, Valgjärve, Upper Ugandi, Lower Ugandi, and Upper Sangaste subformations (Table 1). However, two, occasionally three lowermost till units fill a buried valley beneath a drumlin. The stratigraphic position of till units is usually determined by bedding, i.e. their position relative to interglacial or interstadial deposits. Unfortunately, glacial erosion has removed interglacial or interstadial deposits from the major part of the drumlin field. The only interglacial deposits belong to the Karuküla Formation (Holsteinian) in the southern end of the study area, at Kõrveküla (Fig. 1, borehole 528) near Tartu. The Holsteinian age of the intermorainic organic-containing lacustrine silt, sand, and compacted gyttja deposits has been established by palynological analysis (Liivrand \& Saarse 1983; Liivrand 1991).

Previously, the petrographic composition of coarse clastics and the differences in colour served as criteria to identify and correlate tills in Estonia (Orviku 1958; Raukas 1978). However, the petrographic composition of clastics from boreholes is very hard to determine due to the small size of samples. We have used the compositional data of fine-grained $(<2 \mathrm{~mm})$ material to distinguish different-aged till units and for lithostratigraphical correlations in the Saadjärve Drumlin Field (Fig. 1). The initial purpose of this study was to find lithostratigraphic indices of the fine-grained material for each till unit with respect to the provenance of source material and till-forming processes. We used different lithological properties to prove the existence of five different till units in the study area. Lithostratigraphical correlations enable depiction of the areal distribution and superposition of tills in the drumlin field. By comparing the lithology of these tills with the composition of tills from the areas where their stratigraphic position is confirmed by bio- or chronostratigraphic data, we determined the probable age of the first drumlin-like landforms in the area. 


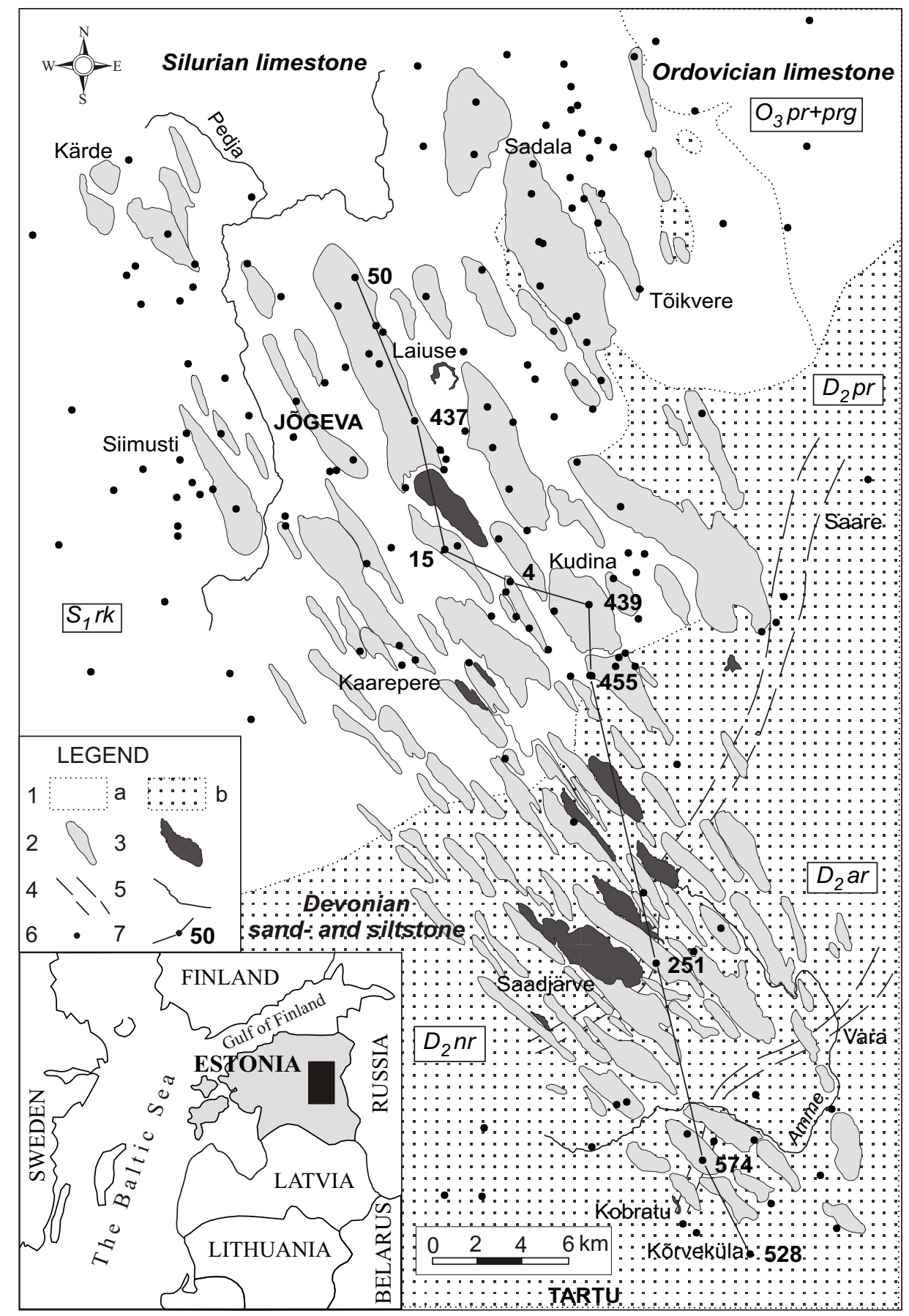

Fig. 1. Geological sketch map of the study area - the Saadjärve Drumlin Field. 1, bedrock outcrop areas: a) limestone $\left(\mathrm{O}_{3} \mathrm{pr}+\mathrm{prg}\right.$ - Porkuni and Pirgu stages, $\mathrm{S}_{1} \mathrm{rk}$ - Raikküla Stage $)$, b) sandstone $\left(\mathrm{D}_{2} \mathrm{pr}\right.$ - Pärnu Stage, $\mathrm{D}_{2} \mathrm{nr}-$ Narva Stage, $\mathrm{D}_{2}$ ar - Aruküla Stage); 2, drumlin; 3, lake; 4, buried valley; 5 , river; 6 , boreholes; 7 , cross-section line. 
Table 1. Correlation of stratigraphical units discussed in the text (after Ehlers et al. 1984; Raukas \& Gaigalas 1993; Raukas \& Kajak 1995)

\begin{tabular}{|c|c|c|c|c|c|c|}
\hline \multirow{2}{*}{ 官 } & \multicolumn{2}{|c|}{ Western Europe } & \multicolumn{2}{|c|}{ Estonia } & \multicolumn{2}{|c|}{ NW Russia } \\
\hline & Horizon & Subhorizon & Formation & Subformation & Horizon & Subhorizon \\
\hline \multirow{5}{*}{ 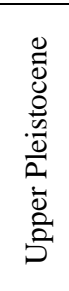 } & \multirow{4}{*}{ Weichselian } & Upper & \multirow{4}{*}{ Järva } & Võrtsjärve & \multirow{4}{*}{ Valdaian } & Ostashkov \\
\hline & & Middle & & Savala & & Leningrad \\
\hline & & \multirow{2}{*}{ Lower } & & Valgjärve & & 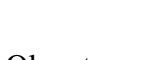 \\
\hline & & & & Kelnase & & \\
\hline & \multicolumn{2}{|l|}{ Eemian } & \multicolumn{2}{|l|}{ Prangli } & \multicolumn{2}{|c|}{ Mikulinan } \\
\hline \multirow{6}{*}{ 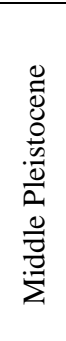 } & \multirow{3}{*}{ Saalian } & Warthe & \multirow{3}{*}{ Ugandi } & Upper Ugandi & \multirow{3}{*}{$\begin{array}{l}\text { Middle } \\
\text { Russian }\end{array}$} & Moscow \\
\hline & & Treene? & & Middle Ugandi & & Odintsovo \\
\hline & & Drenthe & & Lower Ugandi & & Dnieper \\
\hline & \multicolumn{2}{|l|}{ Holsteinian } & \multicolumn{2}{|l|}{ Karuküla } & \multicolumn{2}{|l|}{ Likhvinan } \\
\hline & \multirow[b]{2}{*}{ Elsterian } & & \multirow[b]{2}{*}{ Sangaste } & Upper Sangaste & \multirow[b]{2}{*}{$\begin{array}{l}\text { Bela- } \\
\text { rusian }\end{array}$} & \multirow[b]{2}{*}{ Oka } \\
\hline & & & & $\begin{array}{l}\text { deposits firmly } \\
\text { not determined }\end{array}$ & & \\
\hline
\end{tabular}

\section{MORPHOLOGY AND GEOLOGICAL SETTINGS OF THE STUDY AREA}

The Saadjärve Drumlin Field is located in east-central Estonia, on the distal side of the Pandivere bedrock upland (Fig. 1). Its length is about $55 \mathrm{~km}$, the maximum width reaches $27 \mathrm{~km}$ on the proximal side, decreasing to $10 \mathrm{~km}$ on the distal end. The field is $1200 \mathrm{~km}^{2}$ in area and contains about 100 drumlins and drumlin-like ridges. For the most part, the drumlins are $2-5 \mathrm{~km}$ long, $0.5-0.8 \mathrm{~km}$ wide, and 20-40 m high. Exceptionally large, yet flat and slightly elongated gigantic drumlins (up to $13 \mathrm{~km}$ in length and $3.5 \mathrm{~km}$ in width) prevail in the proximal part of the drumlin field (Rõuk 1987). The orientation of the drumlins, as well as of the whole drumlin field, is parallel to the direction of the last advance of the Late Weichselian glaciation (Rõuk \& Raukas 1989).

The bedrock in the northwestern part of the drumlin field is composed of Lower Silurian limestone and dolomite (Raikküla Stage $-\mathrm{S}_{1} \mathrm{rk}$ ). Bedrock in the southeastern part consists of Middle Devonian silt- and sandstone (Pärnu - $\mathrm{D}_{2} \mathrm{pr}$, Narva $-D_{2}$ nr, and Aruküla $-D_{2}$ ar stages) (Fig. 1). Given the slight monoclinal southward-dipping $\left(11^{\prime}-15^{\prime}\right)$ bedding of the Palaeozoic sedimentary rocks (Rõuk \& Raukas 1989), we infer that during pre-Weichselian glaciations Devonian rocks 
outcropped in the northern part of the drumlin field as well; glacial erosion has shifted the outcrop area of Devonian sandstones noticeably southward. The upper surface of the bedrock lies between $80-90 \mathrm{~m}$ a.s.l. in the northwest, decreasing to about $20 \mathrm{~m}$ a.s.l. in the central part of the drumlin field and rising again up to $50 \mathrm{~m}$ a.s.l. at the southern end (Tavast \& Raukas 1982).

The thickness of Quaternary deposits does not usually exceed $60-70 \mathrm{~m}$, however, thicknesses over $100 \mathrm{~m}$ occur in buried valleys. Two buried valleys, Saadjärve-Saare and Kobratu-Vara, cross the drumlin field in the SW-NE direction. The floor of the buried valleys lies lower than $25 \mathrm{~m}$ b.s.l. near Saare, at $0.6 \mathrm{~m}$ b.s.l. near Saadjärve, and about $2 \mathrm{~m}$ a.s.l. near Kobratu (Kajak 1965). The Quaternary cover of the area as well as the drumlins are composed mostly of Middle and Upper Pleistocene till beds with stratified glaciofluvial and glaciolacustrine deposits. Holocene sediments, $10-15 \mathrm{~m}$ thick, are predominantly gyttja, lake lime, and peat in interstitial troughs.

\section{MATERIAL AND METHODS}

The distribution and compositional data of tills were obtained through the geological mapping of Quaternary deposits on 1:200 000 and 1:50000 scales carried out by the Geological Survey of Estonia. About 190 boreholes have been drilled in the area (Fig. 1), of which 65 penetrate the entire Quaternary cover. On the basis of core descriptions five macroscopically different till units have been distinguished, assigned to the Sangaste (Elsterian glaciation), Ugandi (Saalian), and Järva (Weichselian) formations (Table 1).

The Upper Sangaste till (Elsterian) was determined in the central and distal zones of the drumlin field. The stratigraphic position of the Upper Sangaste till is controlled by overlying interglacial deposits of the Karuküla Formation (Holsteinian) in the southeasternmost corner of the study area, at Kõrveküla. The compact diamicton directly overlies bedrock on the base of the ancient valleys.

The second till unit $($ Lower Ugandi $=$ Drenthenian/Lower Saalian) has been identified by colour (purplish-brown) in two drill cores (Fig. 1, boreholes 251 and 574), which, together with the overlying third till unit (Upper Ugandi $=$ Warthenian/Upper Saalian), fills the buried valleys in the central and distal zones of the drumlin field. In the northern part of the drumlin field the Upper Ugandi till is found in only the biggest drumlins. The till bed reaches a maximum thickness of $25 \mathrm{~m}$ and an absolute altitude of $60 \mathrm{~m}$, but does not outcrop in the study area.

The till of the Valgjärve Subformation (Lower Weichselian) makes up a 14-39 m thick and widespread layer of grey massive diamicton, which underlies a thick sheet of glaciofluvial deposits.

The till of the last glacial advance (Võrtsjärve Subformation = Upper Weichselian) occurs throughout the drumlin field. Its thickness varies between 
2 and $45 \mathrm{~m}$. Many smaller drumlins and flutings in the peripheral part of the drumlin field consist entirely of the Võrtsjärve till.

A total of 360 till samples were collected from 70 boreholes (depth range $0.8-84 \mathrm{~m})$, and the fine-grained material $(<2 \mathrm{~mm})$ was subjected to grain-size, mineralogical, and chemical analysis. Grain-size analysis of sand fractions (2-1, $1-0.5,0.5-0.25,0.25-0.1$, and $0.1-0.05 \mathrm{~mm}$ ) was performed by wet-sieving; the pipette method was used for silt fractions $(0.05-0.01$ and $0.01-0.002 \mathrm{~mm})$ and clay $(<0.002 \mathrm{~mm})$. Four grain-size characteristic coefficients were calculated (Wentworth 1936): arithmetic mean Md (characterizing mean grain size), standard deviation $\sigma$ (characterizing sorting), asymmetric coefficient $\mathrm{Sk}$, and excess E.

The mineralogical composition of tills was analysed in the $0.1-0.25 \mathrm{~mm}$ fraction by the immersion method. Light and heavy minerals were separated in bromophorm $\left(d=2.89 \mathrm{~g} / \mathrm{cm}^{3}\right)$. Approximately 300 light and 500 heavy mineral grains were counted from each sample under a light microscope and calculated as volume percentages (vol\%) and weight percentages (wt $\%)$.

The chemical composition of samples was determined from the $<1 \mathrm{~mm}$ fraction by wet-silicate analysis. Mineral material was dissolved in hydrochloric acid and $\mathrm{KNaCO}_{3} . \mathrm{SiO}_{2}$ was analysed using the gravimetric method, $\mathrm{Al}_{2} \mathrm{O}_{3}, \mathrm{CaO}$, Fe-oxides by titration, $\mathrm{MgO}$ and $\mathrm{MnO}_{3}$ by atomic absorption spectrophotometry, and $\mathrm{TiO}_{2}$ by a photocolorimeter. $\mathrm{K}_{2} \mathrm{O}$ and $\mathrm{Na}_{2} \mathrm{O}$ were analysed by using flame photometry.

\section{RESULTS}

The general distribution of till units and their grain-size distribution, mineralogical and chemical composition point to common factors involved in till formation during different ice advances, reflected in the drumlins in the study area. The summary of laboratory analyses of the major lithological properties is shown in Table 2.

\section{Grain-size distribution}

Detailed analysis of the granulometric composition of the fine fraction of tills showed an unsorted particle-size distribution. The content of different fractions varies greatly with till units. The analysed tills are mostly of sandy loam containing $50-75 \%$ sand $(2-0.05 \mathrm{~mm})$ on an average.

The Upper Sangaste till has a distinct bimodal distribution of fine-grained fractions with maximums of fine sand $(0.1-0.25 \mathrm{~mm})$ and fine silt $(0.01-0.002 \mathrm{~mm})$ fractions (Fig. 2). The till has a very high silt content (37.5\%), resulting from glacial abrasion and attrition of soft fine-grained bedrock (sandstones).

The Upper Ugandi till has an almost unimodal particle distribution with a maximum in medium sand fraction $(0.5-0.25 \mathrm{~mm})$, and consequently, is better 


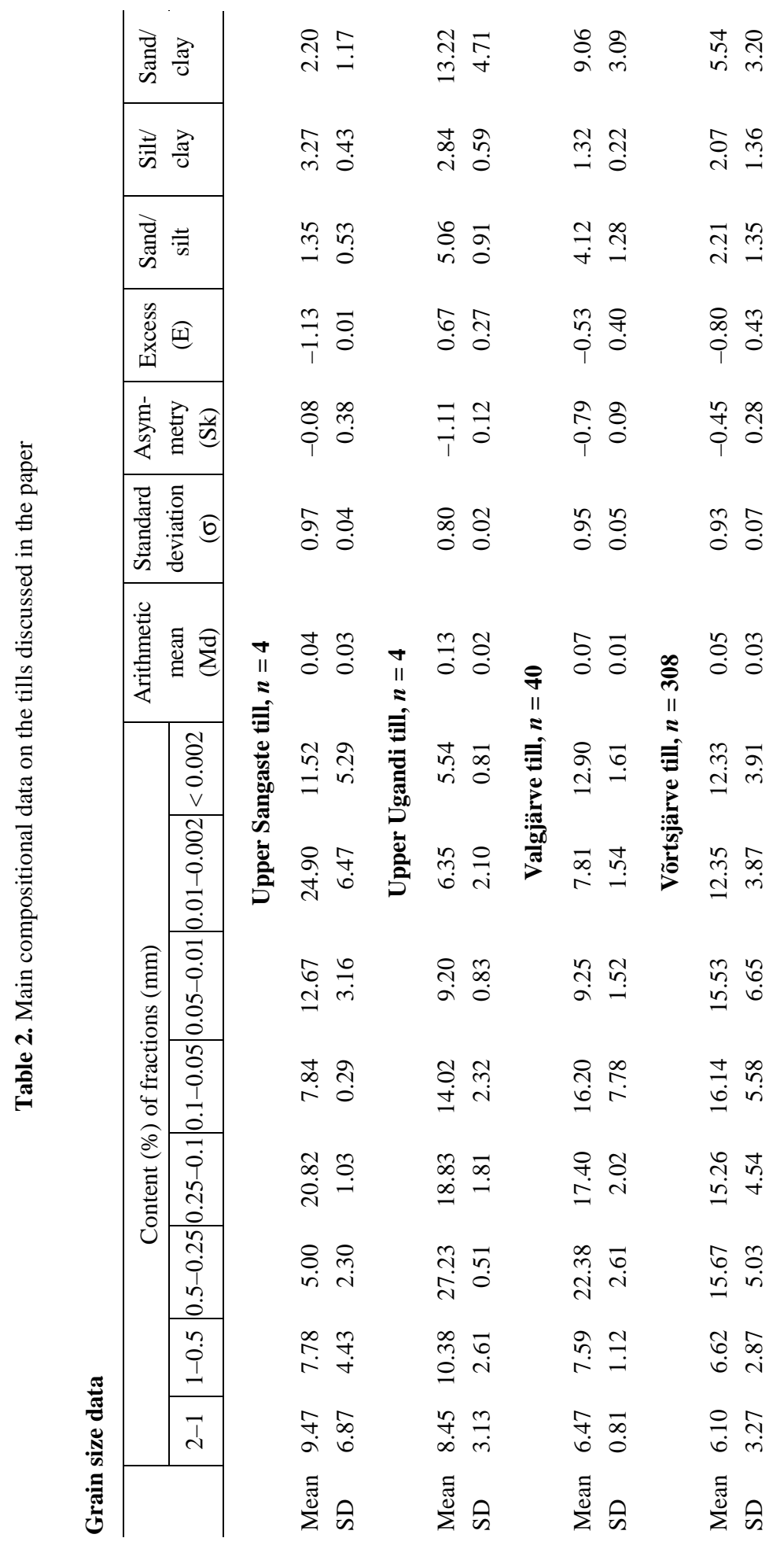




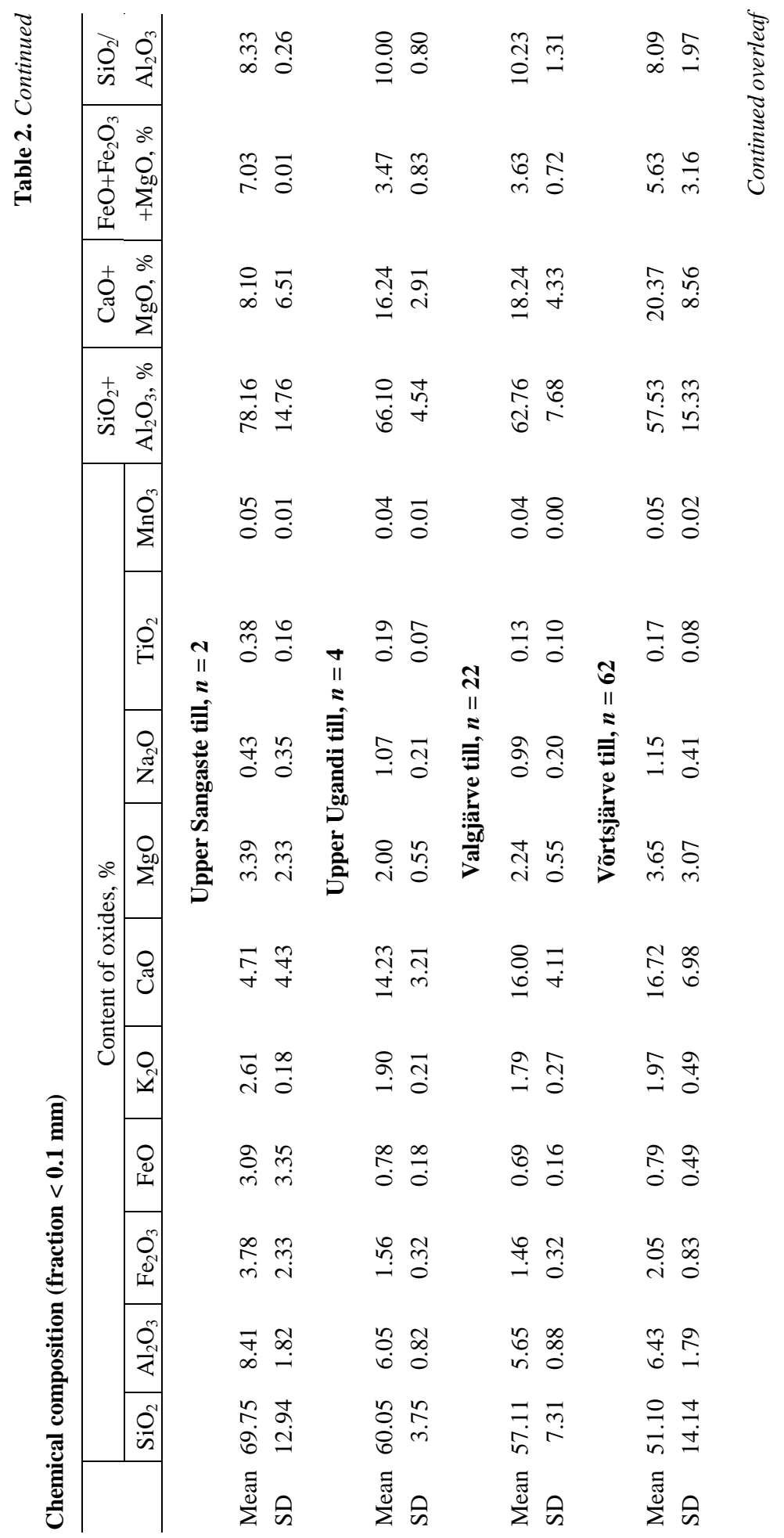




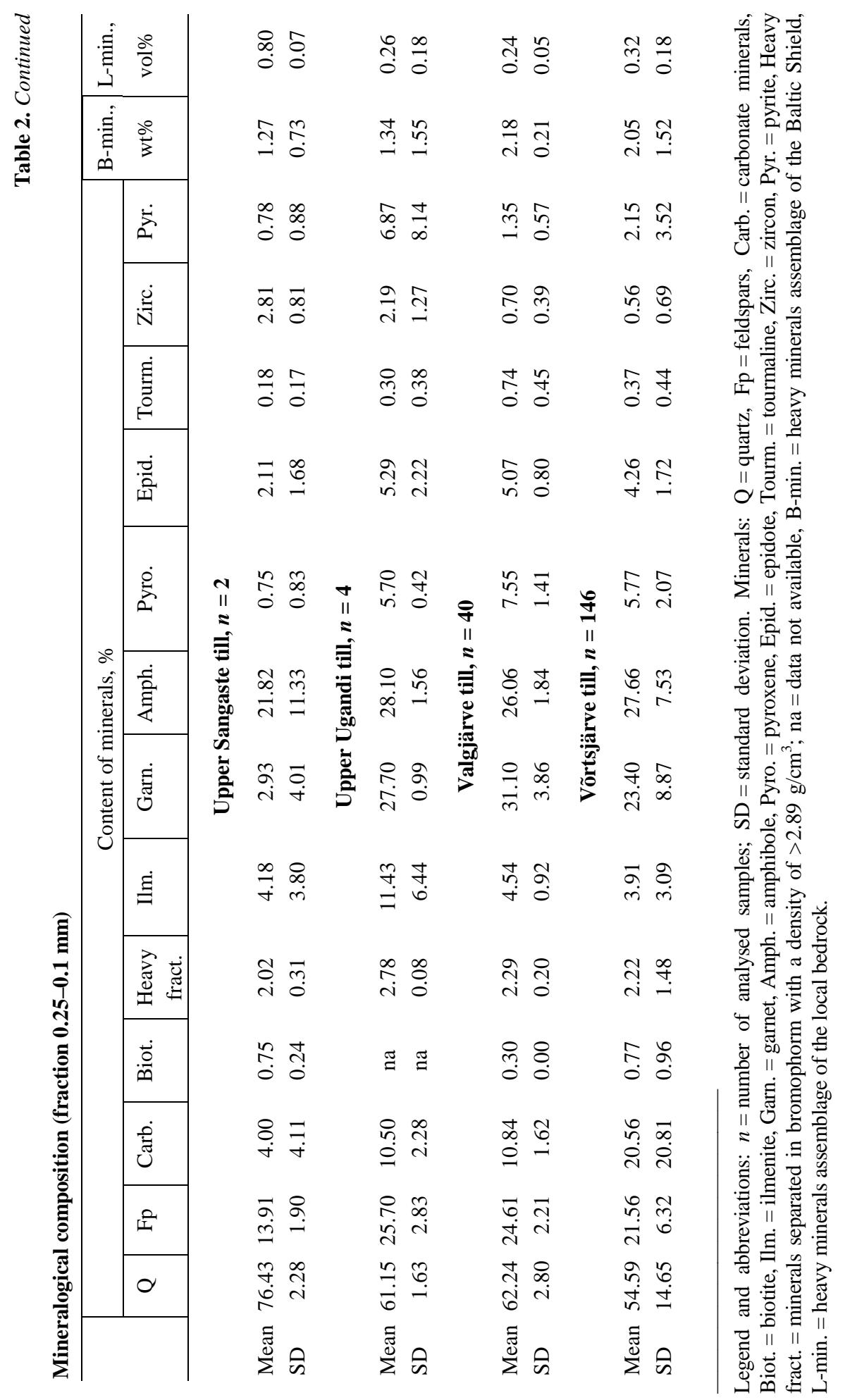




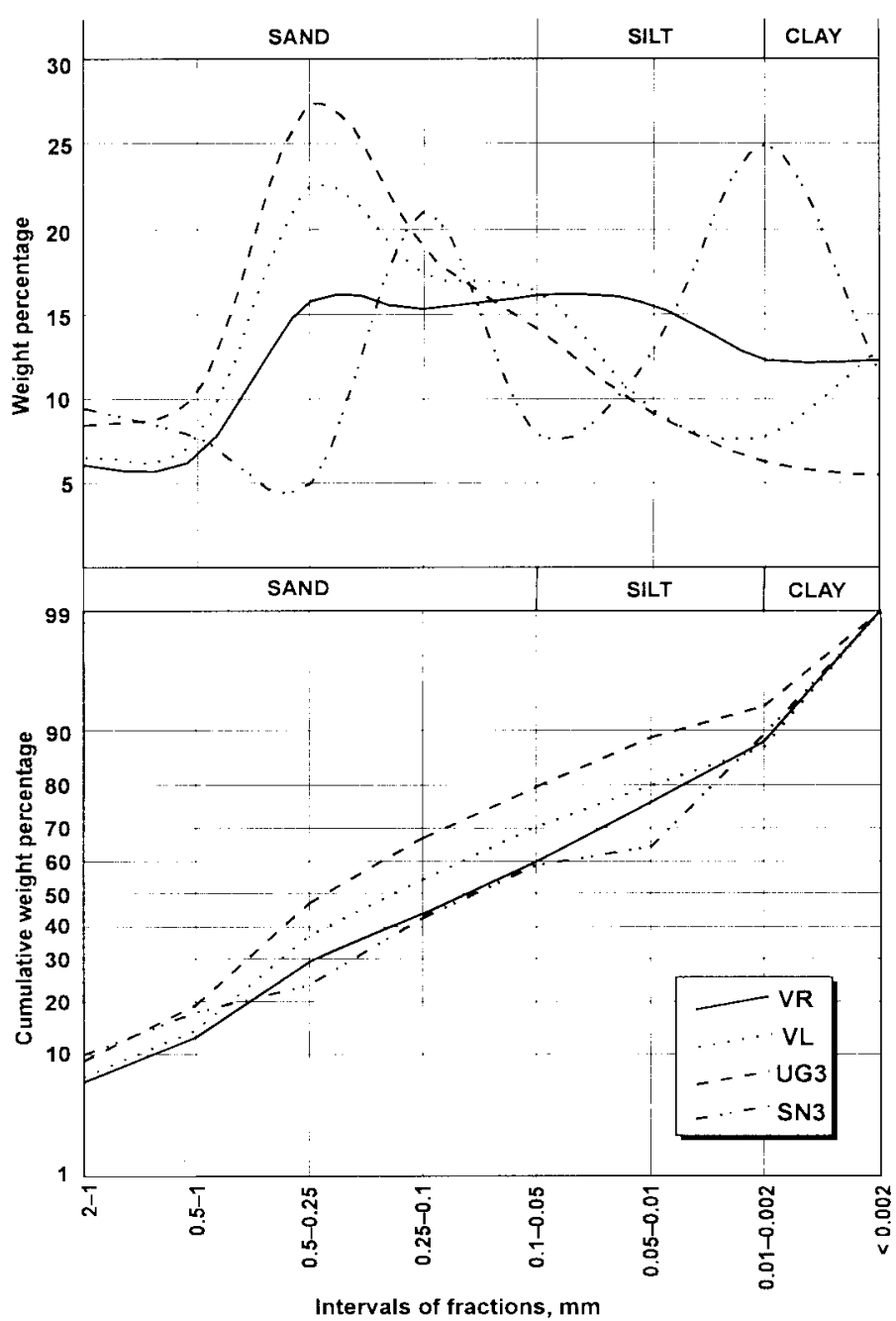

Fig. 2. Distribution and cumulative curves of the average composition of different till units. VR, Võrtsjärve; VL, Valgjärve; UG3, Upper Ugandi; SN3, Upper Sangaste.

sorted. The highest mean grain size fraction of this till is accompanied by a low silt and clay content. Similarly to Dreimanis (1989) model, the particle-size distribution of the Upper Ugandi till may indicate the role of meltwater during deposition, when part of finer debris may have been removed. Consequently, the till has a greater mean grain size and better sorting of fine-grained debris.

The Valgjärve and Võrtsjärve tills have a polymodal particle distribution. The particle-size distribution of the Valgjärve till is homogeneous, foremost in drumlins, indicating stable depositional conditions and distribution of source material in the basal ice beds. Alternatively, it may result from erosion and 


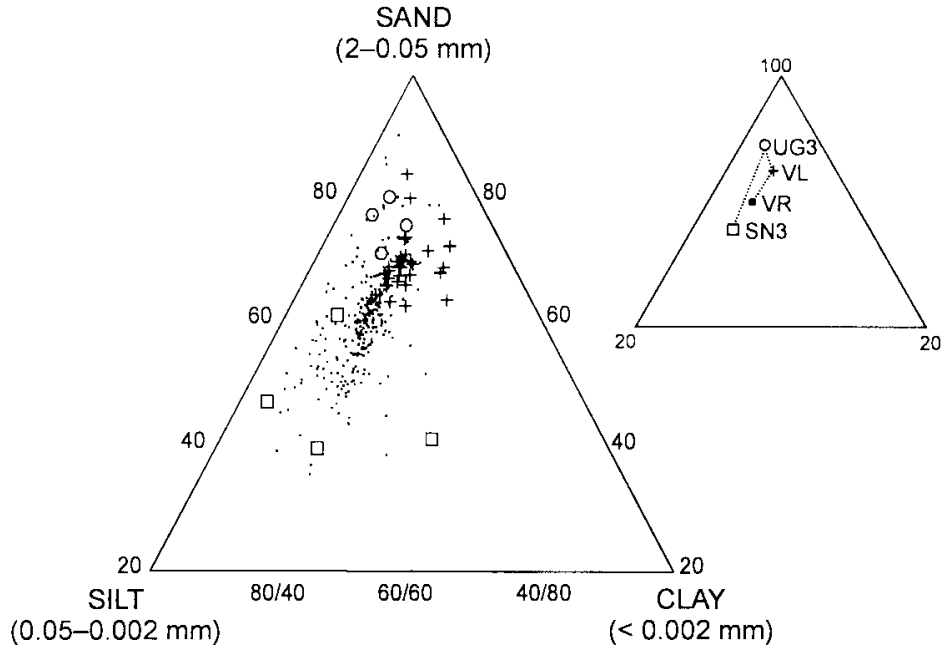

Fig. 3. The distribution of till samples in a ternary diagram. The small triangle shows the average values for different till units. VR, Võrtsjärve; VL, Valgjärve; UG3, Upper Ugandi; SN3, Upper Sangaste.

deposition produced by ice sheet resting on an unlithified sediment bed (Boulton 1996). Sorting and mean grain size of the Vorrtsjärve till vary greatly. The irregular sorting, finer and coarser interlayers, suggest complicated subglacial depositional and hydrological conditions. The ternary diagram shows a stable clay fraction (less than 27\%) in the Võrtsjärve till, and greater variations in sand and silt fractions (Fig. 3).

\section{Mineralogical composition}

Data on the mineralogical composition support the lithological distinction of the Upper Sangaste till from the others (Table 2). The total heavy mineral content in fine sand fraction $(0.1-0.25 \mathrm{~mm})$ varies up to $5 \%$, but the Vorrtsjärve till, distributed on the plain west of the drumlins and containing 90\% local carbonaceous rocks, has higher concentrations of the heavy fraction $(8-12.2 \%)$, mainly due to opaque minerals, such as ilmenite and magnetite. The contents of different heavy minerals are unstable and their internal distribution reflects source, transport, sedimentation, and weathering conditions of debris (Juozapavičius 1976; Haldorsen 1978, 1983; Lang \& Stevens 1999). The Scandinavian glaciers scoured the crystalline rocks of the Baltic (Fennoscandian) Shield and the local carbonaceous (Ordovician and Silurian) and terrigenous (Devonian) rocks (hereafter $\mathrm{B} / \mathrm{L}$ ratio). In this study we compared the relationship between heavy mineral assemblages typical of the Baltic Shield (apatite, amphiboles, pyroxenes, zircon, garnet, epidote, tourmaline, staurolite, sphene, 
corundum, sillimanite, monazite, magnetite, and ilmenite) and the local bedrock (hematite, leucoxene, pyrite, micas, limonite, phosphates, carbonates, anatase, barite, and chlorite) (Juozapavičius 1976; Viiding 1976).

The correlation between these heavy mineral assemblages is poor for all samples in the study area (Fig. 4). The Upper Sangaste till has an almost equal amount of each heavy mineral assemblage (B/L ratio 1.6). A high content of local heavy minerals stems from high contents of micas, hematite, limonite, and phosphates, which likely originated from the underlying Devonian sandstone. Some Baltic Shield minerals may also originate from the Devonian sandstone. Garnet, epidote, tourmaline, and zircon are very common allothigenous heavy minerals in the Devonian sandstone (Viiding 1962, 1968), but the contents of these minerals (except zircon) are very low in the Upper Sangaste till.

The Upper Ugandi till contains over five times more heavy minerals of the Baltic Shield than of the local bedrock assemblage (B/L ratio 5.2), owing to higher contents of ilmenite, epidote, and amphiboles. The till has a high concentration of carbonates in fine sand and also dolomitized limestones of the outcropping Raikküla Regional Stage in fine gravel.

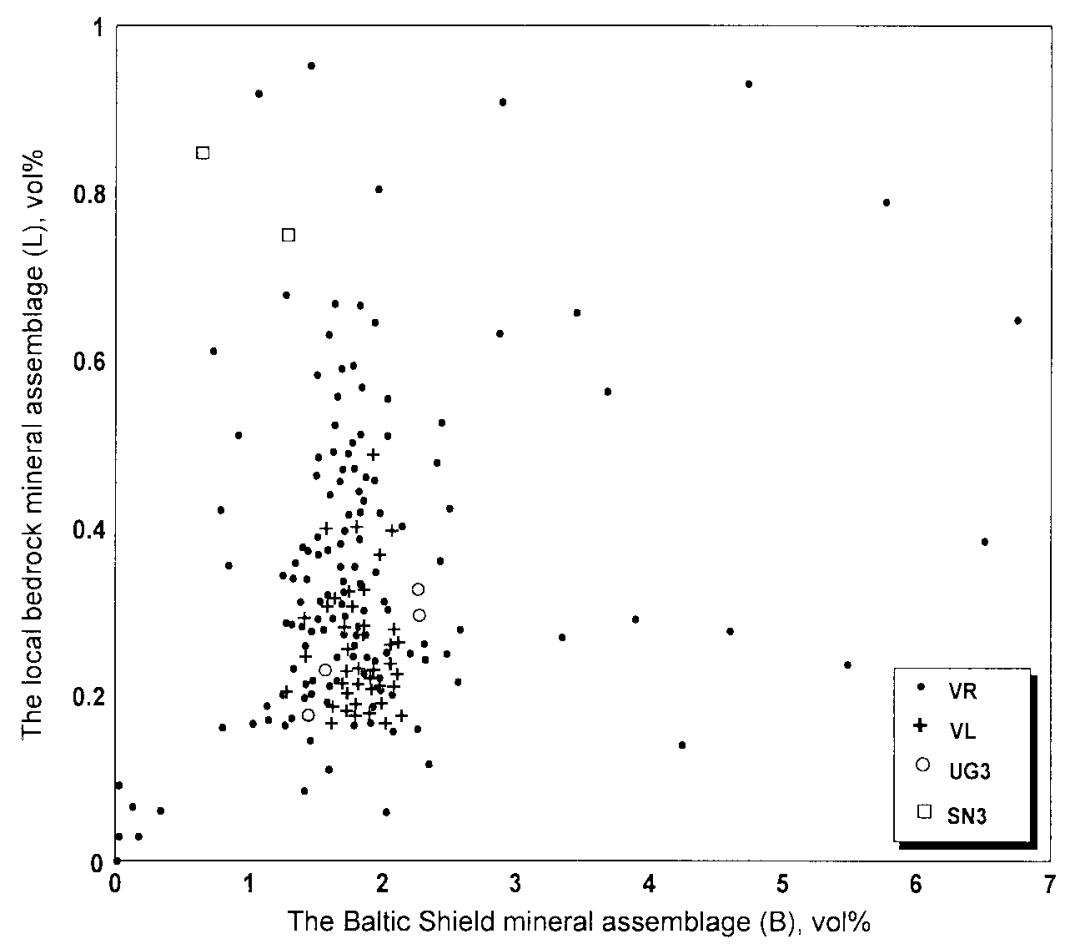

Fig. 4. Relationship between the Baltic Shield (B) and the local bedrock (L) heavy mineral assemblages in different till units. VR, Võrtsjärve; VL, Valgjärve; UG3, Upper Ugandi; SN3, Upper Sangaste. 
The Valgjärve till has a $\mathrm{B} / \mathrm{L}$ ratio of 9.1 . The high contents of garnet, pyroxene, and tourmaline, as well as quartz and feldspars $(\mathrm{Q}+\mathrm{Fp})$, indicate either intense glacial erosion on the shield or abrasion of earlier deposited unconsolidated sediments in the drumlin field. The latter is supported by the lower concentration of fine sand in the Valgjärve till with respect to the Upper Ugandi till, and as according to the theory of terminal grades (Haldorsen 1981) calcite and dolomite were restricted to silt fraction, fine sand fraction was enriched with quartz.

The Võrtsjärve till shows great variation in all minerals. The till contains a large amount of local bedrock material. The carbonate content is over twice as large as the average of the other tills $(20.56 \%)$.

\section{Chemical composition}

The chemical composition of the till units reflects mainly the mineral composition inherited from source material, the till-forming processes, and epigenetical factors, such as winnowing and soil weathering (Haldorsen 1983). The variation of chemical composition is lower than that of mineral composition (Table 2). The Upper Sangaste till has a high concentration of $\mathrm{SiO}_{2}, \mathrm{Al}_{2} \mathrm{O}_{3}, \mathrm{TiO}_{2}$, and iron oxides. The $\mathrm{SiO}_{2}$ concentration decreases in the direction from the Upper Sangaste till (older) to the Valgjärve till (younger), which is compensated by a gradual increase in $\mathrm{CaO}+\mathrm{MgO}$. A somewhat elevated concentration of $\mathrm{Fe}_{2} \mathrm{O}_{3}$ within all till horizons might be related to differences in oxidation-reducing conditions (Raukas 1978).

\section{DISCUSSION AND POSSIBLE LITHOSTRATIGRAPHICAL CORRELATIONS}

The distribution and stratigraphy of the established and studied till units along the Saadjärve Drumlin Field are shown in Fig. 5 (see also Fig. 1).

The Upper Sangaste till, probably the oldest in the area, occurs in the central and distal zones of the drumlin field. The compact, soiled-brown diamicton directly overlies bedrock at the bottom of the ancient valleys (boreholes 251 and 574) and at the distal end of the drumlin field at Kõrveküla (borehole 528, Figs. 1 and 5), where the age of the till is determined by the overlying Holsteinian interglacial deposits. The composition of fine clasts of the Upper Sangaste till contrasts strongly with the other tills. The bimodal grain-size distribution and extremely high silt content in the Upper Ugandi till are the result of glacial abrasion and attrition of soft, fine-grained Devonian bedrock (sandstones) (Haldorsen 1981). In addition, analyses of microtextures on quartz grains (from borehole 528) has suggested incorporation of preweathered sand from the underlying Devonian sandstone (Mahaney \& Kalm 1995). The high content of local 


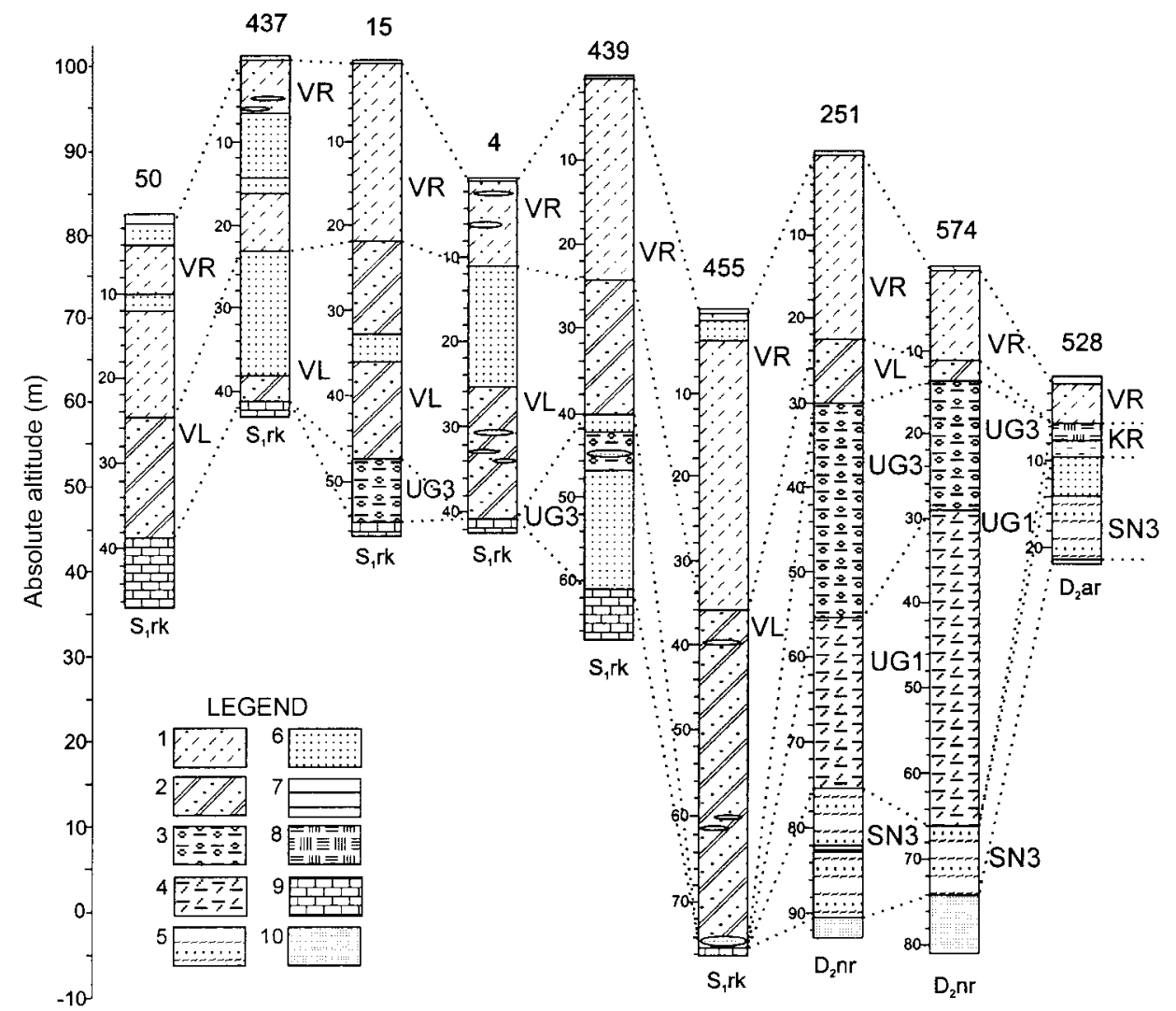

Fig. 5. Stratigraphic division and correlation of till units in the Saadjärve Drumlin Field (boreholes lie along the line shown in Fig. 1). 1, Võrtsjärve till (VR); 2, Valgjärve till (VL); 3, Upper Ugandi till (UG3); 4, Lower Ugandi till (UG1); 5, Upper Sangaste till (SN3); 6, glaciofluvial deposits of different age; 7, glaciolacustrine deposits of different age; 8 , interglacial deposits of the Karuküla Formation (KR); 9 , limestone ( $\mathrm{S}_{1} \mathrm{rk}$ - Raikküla Stage, Lower Silurian); 10, sandstone $\left(\mathrm{D}_{2} \mathrm{nr}\right.$ - Narva Stage, $\mathrm{D}_{2} \mathrm{ar}-$ Aruküla Stage, Middle Devonian).

heavy minerals (Table 2, Fig. 4), especially micas, hematite, limonite, and phosphates, and quartz can be attributed in part to the underlying sandstone. However, the low content of garnet, tourmaline, and epidote, very common allothigenous heavy minerals in Devonian sandstone, is due to their resistivity and subsequent higher concentrations in larger fractions (Juozapavičius 1976), which were not studied. The petrographic composition of clasts in the diamicton shows the prevalence of carbonates, although the content of crystalline rocks can amount to 45\% (Kajak 1965; Raukas 1978; Kajak et al. 1990). The content of carbonates of fine sand is very low (Table 2).

The distribution and correlation of the Lower Ugandi till is the most uncertain. Originally the till was identified by colour (purplish-brown) in two drill cores 
(boreholes 251 and 574). Together with the overlying purplish-grey till (determined as Upper Ugandi) it fills the buried valleys (Kajak 1965). Earlier studies have shown that both diamictons are lithologically similar (Kajak 1965; Raukas 1978).

The Upper Ugandi till is sporadically established throughout the drumlin field area, chiefly in cores of the biggest drumlins. The compositional data - higher concentration of carbonates in sand fraction (Table 2) and domination of dolomitized limestone debris in gravel fraction (unpublished geological mapping report) - suggest a greater influence of the local carbonaceous rocks on the tillforming processes. A higher carbonate content is observed also in the Devonian sandstone outcrop areas in southern Estonia (Orviku 1958; Kajak 1965; Raukas 1978; Kajak et al. 1990). The particle-size distribution of the Upper Ugandi till may also indicate the role of meltwater during deposition, when some of finer debris may have been washed away. The low silt and clay contents and prevalence of sand fractions indicate crushing of the glacier on more resistant bedrock (Haldorsen 1981). The Upper Ugandi till is most probably a melt-out till: some of the finegrained debris was carried away by meltwater, thus the mean grain size increased and the sorting improved (Dreimanis 1989).

The Valgjärve till represents a thick (14-39 m) and widespread layer of grey homogeneous diamicton. Thick beds (up to $60 \mathrm{~m}$ ) of glaciofluvial sand and gravel occur between two uppermost till units in the northwestern part of the drumlin field. Previous works (Rõuk 1974a, 1976, 1984; Rõuk \& Raukas 1989) do not interpret these deposits as fluviatile infills of subglacial cavities or erosional remnants of catastrophic meltwater discharges of the entire drumlin form (Shaw \& Sharp 1987) during the Late Weichselian ice advance. These glaciofluvial deposits designate the position of the Valgjärve till in the Estonian stratigraphical scheme (Table 1). The Valgjärve till has a larger mean grain size, a higher concentration of fine sand fraction, higher contents of Baltic Shield heavy minerals and $\mathrm{SiO}_{2} / \mathrm{Al}_{2} \mathrm{O}_{3}$ ratio, but lower contents of silt, feldspar, and $\mathrm{CaO}+\mathrm{MgO}$ (Table 2) than the Vorrtsjärve till.

The Võrtsjärve till is distributed throughout the drumlin field. Its colour in the Ordovician and Silurian carbonate outcrop area is grey, whereas the till overlying Devonian sand- and siltstone is reddish-brown. The composition of the till is very heterogeneous, indicating sedimentologic conditions of debris caused by peculiarities of intradynamic ice. The variation in the Vorrtsjärve till may be the result of a variety of sedimentation processes and of variable distribution of substrate material. The temperature gradient of the base surface and the glacial base determine glacier movement velocity, and consequently also the relationship between erosion and accumulation, as well as freezing of debris in the glacier or of the base surface (Drewry 1986).

The jagged or wavy foot-line of drumlins at the eastern border of the drumlin field suggests the formation to be the result of irregular accumulation of till and of meltwater erosion in the final phase of development (Rõuk 1976), and also of 
melting of stagnant ice and deposition on the account of supraglacial and partly englacial debris. The characteristic feature of this till is a higher concentration of sand fraction and a higher content of the Baltic Shield heavy minerals as well as quartz and feldspar (Table 2). The plains west and northwest of the drumlin field were elevated areas of bedrock, which decelerated glacier movement and decreased basal glacier velocity, and consequently, accumulation of local basal till. According to the formation of erosion and accumulation areas, debris was carried away from the slopes of hills and valleys and accumulated behind the hills or on plains. The debris was dragged by the glacier, but was not frozen in its base, and was deposited near the site of erosion. The till consists of a large amount of local bedrock material (up to $90 \%$ ). Therefore, the Vorrtsjärve till has a high concentration of carbonates and $\mathrm{CaO}+\mathrm{MgO}$ (Table 2).

\section{CONCLUSIONS}

Analysis shows that stratigraphical correlation of tills cannot be based on any single lithological characteristic. First of all, the lithological and chemical compositions of tills reflect the dynamical conditions of glaciers and till-forming processes. However, the till units in the Saadjärve Drumlin Field are lithostratigraphically correlated with respect to bedrock composition and surface topography, the distribution of glacial sediments and their compositional characteristics.

The compositional characteristics of the lowermost till unit differ distinctly from the others. The bimodal grain-size distribution with a greater content of fine sand and coarse silt and almost equal contents of Baltic Shield and local bedrock heavy mineral assemblages reflect the great influence of the Devonian sand- and siltstones on basal transport of debris by ice. Because the stratigraphic position of this till is controlled by the Holsteinian interglacial deposits, the till is at least of Elsterian age and corresponds to the Upper Sangaste Subformation.

There are no lithological differences between tills formed by different ice advances of the Saalian glaciation (Lower Ugandi and Upper Ugandi subformations). The corresponding tills, compared to the others, are characterized by a larger mean grain size and better sorting, and by a higher content of carbonates in fine sand fraction, as well as in coarse-grained material. The higher content of carbonates indicates crushing activity of the glacier in the carbonate outcrop area with the debris being released in the drumlin field by subglacial melting.

The Weichselian tills (Valgjärve and Võrtsjärve subformations) were formed by abrasion, transport, and attrition of earlier deposited unconsolidated sediments in the drumlin field. The compositional characteristics show great homogeneity of the Valgjärve till, unlike the Vorrtsjärve till. Variation in the lithological composition of the latter is the result of a variety of controls of sedimentation processes in drumlins and on the neighbouring plane to the west. 
The stratigraphy and distribution of tills in the Saadjärve Drumlin Field prove that drumlins are products of several glacial advances and started to form at least during Saale glaciation. The final formation and morphology are likely related to the general retreat of the last, Late Weichselian glacier.

\section{ACKNOWLEDGEMENTS}

The authors thank the Geological Survey of Estonia for the opportunity to use the geological mapping data and for laboratory analysis. We owe special gratitude to A. Einmann for the permission to use his unpublished materials. The research was supported by grant TBGGL 0550 of the Estonian Science Foundation.

\section{REFERENCES}

Aario, R. \& Heikkinen, O. (eds.). 1992. Proceedings of the Third International Drumlin Symposium. Geomorphology, 6.

Barkla, H. 1935. The drumlins of Türi (Estonia). Publ. Geol. Inst. Univ. Tartu, 48, 1-11.

Boulton, G. S. 1996. Theory of glacial erosion, transport and deposition as a consequence of subglacial sediment deformation. J. Glaciol., 42, 43-62.

Dardis, G. F. \& McCabe, A. M. (eds.). 1994. Subglacial processes, sediments and landforms. Sedim. Geol., 91.

Dreimanis, A. 1989. Tills: their genetic terminology and classification. In Genetic Classification of Glacigenic Deposits (Goldthwait, R. P. \& Matsch, C. L., eds.), pp. 17-83. Balkema, Rotterdam.

Drewry, D. 1986. Glacial Geologic Processes. Edward Arnold, London.

Ehlers, J., Meyer, K.-D. \& Stephan, H.-J. 1984. Pre-Weichselian glaciations of North-West Europe. Quat. Sci. Rev., 3, 1-40.

Eltermann, G. \& Raukas, A. 1963. Some examples of comparison by lithological methods of macroscopically similar moraines of different age. ENSV TA Geol. Inst. Uurimused, 12, 23-37 (in Russian).

Goldstein, B. 1989. Lithology, sedimentology, and genesis of the Wadena drumlin field, Minnesota, U.S.A. Sedim. Geol., 62, 241-277.

Haldorsen, S. 1978. Glacial comminution of mineral grains. Norsk Geol. Tidsskr., 58, 241-243.

Haldorsen, S. 1981. Grain-size distribution of subglacial till and its relation to glacial crushing and abrasion. Boreas, 10, 91-105.

Haldorsen, S. 1983. Mineralogy and geochemistry of basal till and their relationship to till-forming processes. Norsk Geol. Tidsskr., 63, 15-25.

Hausen, H. 1913. Materialen zur Kenntnis der Pleistozänen Bildungen in den russischen Ostseeländern. Fennia, 34.

Juozapavičius, G. 1976. Methodik mineralogischer Untersuchungen zwecks Rekonstruktion der Sandbildungsbedingungen (am Beispiel von Litauischen SSR). In Methodik und Interpretation der Ergebnisse mineralogischer und geochemischer Untersuchungen (Narbutas, V., ed.), pp. 22-30. Mokslas, Vilnius (in Russian).

Kajak, K. 1965. On the geology of drumlins of Saadjärv. In Litologiya i stratigrafiya chetvertichnykh otlozhenij Éstonii (Orviku, K. K., ed.), pp. 23-28. Inst. Geol. AN ESSR, Tallinn (in Russian). 
Kajak, K., Saarse, L., Raukas, A., Utsal, K. \& Kalm, V. 1990. On the composition of differently coloured tills in southern Estonia. In The Quaternary Methods of Investigation, Stratigraphy and Ecology, pp. 58-60. Papers for the 7th All-Union Conference, Tallinn (in Russian).

Lang, L.-O. \& Stevens, R. L. 1999. Source, transport, and weathering influences upon grain-size and heavy mineral trends in glacial deposits of southwestern Sweden. GFF, 121, 145-153.

Liivrand, E. 1991. Biostratigraphy of the Pleistocene Deposits in Estonia and Correlations in the Baltic Region. Doctoral thesis, Department of Quaternary Research, Stockholm University, Report 19.

Liivrand, E. \& Saarse, L. 1983. Interglacial deposits in the Kõrveküla section (southeastern Estonia) and their stratigraphic importance. In Palynologic Researches in Geologic Studies of the Baltic Region and the Baltic Sea (Bartosh, T., ed.), pp. 41-59. Zinatne, Riga (in Russian).

Mahaney, W. C. \& Kalm, V. 1995. Scanning electron microscopy of Pleistocene tills in Estonia. Boreas, 24, 13-29.

Menzies, J. 1979. The mechanics of drumlin formation with particular reference to the charge in pore-water content of the till. J. Glaciol., 22, 373-384.

Menzies, J. 1984. Drumlins: a Bibliography. Geo Books, Norwich.

Menzies, J. \& Rose, J. (eds.). 1987. Drumlin Symposium. Balkema, Rotterdam.

Menzies, J. \& Rose, J. (eds.). 1989. Subglacial Bedforms - Drumlins, Rogen Moraine and Associated Subglacial Bedforms. Sedim. Geol., 62.

Orviku, K. 1958. Lithological investigation of the till of the last glaciation in Estonia by quantitative methods. ENSV TA Geol. Inst. Uurimused, 3, 213-252 (in Russian).

Orviku, K. 1961. Geological structure of drumlins in Estonia. In Materialy Vsesoyuznogo soveshchaniya po izucheniyu chetvertichnogo perioda, Vol. 2, pp. 64-72. Moscow (in Russian).

Raukas, A. 1978. Pleistotsenovye otlozheniya Éstonskoj SSR. Valgus, Tallinn (in Russian).

Raukas, A. \& Gaigalas, A. 1993. Pleistocene glacial deposits along the eastern periphery of the Scandinavian ice sheets - an overview. Boreas, 22, 214-222.

Raukas, A. \& Kajak, K. 1995. Quaternary stratigraphy in Estonia. Proc. Estonian Acad. Sci. Geol., 44, 149-162.

Raukas, A. \& Tavast, E. 1994. Drumlins location as response to bedrock topography on the southeastern slope of the Fennoscandian Shield. Sedim. Geol., 91, 373-382.

Rõuk, A.-M. 1972. Türi voorestiku geomorfoloogiast. In Eesti Geograafia Seltsi Aastaraamat 1970 (Merikalju, L., ed.), pp. 19-37. Valgus, Tallinn.

Rõuk, A.-M. 1974a. Voorte ja voorelaadsete pinnavormide morfoloogiline vaheldusrikkus Saadjärve voorestikus. In Eesti Geograafia Seltsi Aastaraamat 1973 (Merikalju, L., ed.), pp. 5-35. Valgus, Tallinn.

Rõuk, A.-M. 1974b. On the till structures in the drumlins of Central Estonia. ENSV TA Toim. Keemia Geol., 23, 147-160 (in Russian).

Rõuk, A.-M. 1976. Drumlins and drumlin-like landforms in the North-East Baltic. In Estonia: Regional Studies, pp. 21-33. Acad. Sci. ESSR, EGS, Tallinn.

Rõuk, A.-M. 1984. Eesti voorte ja voorelaadsete pinnavormide kujunemise probleeme. In Eesti Geograafia Seltsi Aastaraamat 1980 (Merikalju, L., ed.), pp. 49-55. Valgus, Tallinn.

Rõuk, A.-M. 1987. Physiography of the central part of Saadjärv Drumlin Field with special reference to Lake Raigastvere and its surroundings. In Palaeohydrology of the Temperate Zone II. Lakes (Raukas, A. \& Saarse, L., eds.), pp. 81-100. Valgus, Tallinn.

Rõuk, A.-M. \& Raukas, A. 1989. Drumlins of Estonia. Sedim. Geol., 62, 371-384.

Shaw, J. \& Sharp, D. R. 1987. Drumlin formation by subglacial meltwater erosion. Can. J. Earth Sci., 24, 2316-2322.

Tavast, E. \& Raukas, A. 1982. Rel'ef korennykh porod Éstonii. Valgus, Tallinn (in Russian).

Viiding, H. 1962. On the mineralogic composition of Estonian Middle-Devonian sandstones. ENSV TA Geol. Inst. Uurimused, 10, 261-272 (in Russian). 
Viiding, H. 1968. Lithology, mineralogy and genesis of terrigenous Devonian deposits in the North Baltic. In Genesis and Classification of Sedimentary Rocks (Yablokov, V. S., ed.), pp. 7581. International geological congress, XXIII Session, Reports of Soviet geologists, Problem 8. Nauka, Moscow (in Russian).

Viiding, H. 1976. Über die Interpretation mineralogischer Analyseergebnisse. In Methodik und Interpretation der Ergebnisse mineralogischer und geochemischer Untersuchungen (Narbutas, V., ed.), pp. 53-59. Mokslas, Vilnius (in Russian).

Wentworth, C. K. 1936. The method of moments. J. Sedim. Petrol., 6, 158-159.

\title{
MOREENIDE LITOSTRATIGRAAFIA JA LEVIK SAADJÄRVE VOORESTIKUS
}

\author{
Maris RATTAS ja Volli KALM
}

On uuritud moreenikihtide levikut Saadjärve voorestikus ja nende peenpurdmaterjali $(<2 \mathrm{~mm})$ litoloogilist koostist kui võimalikku moreenide stratigraafilise korreleerimise alustunnust. Ülem-Sangaste, Ülem-Ugandi, Valgjärve ja Võrtsjärve alamkihistute moreenidel on selgelt erinevad litoloogilised tunnused. Nii makroskoopiliste kui ka peenpurdmaterjali litoloogiliste tunnuste põhjal ei olnud võimalik eristada Alam-Ugandi alamkihistu moreeni. Seetõttu on mõeldav, et voorestikus esineb ainult üks Saale jäätumise moreen (Ülem-Ugandi). Moreenide leviku ja litostratigraafia põhjal tõestub voorte akretsiooniline päritolu: nende moodustumine algas juba Saale jäätumise perioodil.

\section{ЛИТОСТРАТИГРАФИЯ И РАСПРОСТРАНЕНИЕ МОРЕН НА СААДЬЯРВЕСКОМ ДРУМЛИНОВОМ ПОЛЕ, ВОСТОЧНО-ЦЕНТРАЛЬНАЯ ЭСТОНИЯ}

\author{
Марис РАТТАС и Волли КАЛМ
}

\footnotetext{
Изучены разновозрастные морены Саадъярвеского друмлинового поля по распространению и литологическому составу мелкозернистого материала (<2 мм). По литологическим характеристикам различаются выртсъярвеская и валгъярвеская (обе ранневалдайские), верхнеугандиская (московская) и верхнесангастеская (окская) морены. Макроскопически и по литологическому составу мелкозернистого материала не различаются две угандиские (среднерусские) морены. Литостратиграфия морен подтверждает унаследованное происхождение друмлинов, которые стали формироваться на Саадъярвеском друмлиновом поле во время московского оледенения.
} 